NBER WORKING PAPER SERIES

\title{
MACROECONOMICS CHALLENGES AND RESILIENCE OF EMERGING MARKET ECONOMIES
}

\author{
Joshua Aizenman \\ Working Paper 26361 \\ http://www.nber.org/papers/w26361 \\ NATIONAL BUREAU OF ECONOMIC RESEARCH \\ 1050 Massachusetts Avenue \\ Cambridge, MA 02138 \\ October 2019
}

Joshua Aizenman acknowledges funding from the Asian Development Bank Institute. The views expressed herein are those of the author and do not necessarily reflect the views of the National Bureau of Economic Research.

NBER working papers are circulated for discussion and comment purposes. They have not been peer-reviewed or been subject to the review by the NBER Board of Directors that accompanies official NBER publications.

(C) 2019 by Joshua Aizenman. All rights reserved. Short sections of text, not to exceed two paragraphs, may be quoted without explicit permission provided that full credit, including () notice, is given to the source. 
Macroeconomics Challenges and Resilience of Emerging Market Economies

Joshua Aizenman

NBER Working Paper No. 26361

October 2019

JEL No. F02,F31,F33,F36,F4,F42

\begin{abstract}
A Growing share of Emerging Markets (EMs) use hybrid versions of inflation targeting (IT) that differ from the IT regimes of OECD countries. Policy interest rates among commodity countries are impacted by real exchange rate and international reserves (IR) changes, aiming at stabilizing their real exchange rate in the presence of volatile terms of trade and heightened exposure to capital inflow/outflow shocks. IT works well with independent central banks; yet, fiscal dominance concerns may hinder the efficacy and independency of central banks. This suggests experimenting with the integration of monetary rules with fiscal rules, possibly linking these rules with the operations of buffers like IR and Sovereign Wealth Funds (SWFs). The Global Financial Crisis validated the benefits of counter-cyclical management of international reserves and SWFs in reducing the volatility of real exchange rates. Macro-prudential policies may complement or even substitute buffer policies by reducing a country's balance sheet exposure to foreign currency debt, mitigating the risk of costly sudden-stops and capital flight. A growing share of EMs is exposed to new financial technologies (fintech), providing cheaper and faster financial services, deepening financial coverage to previously under-served populations. Deeper fintech diffusion may redirect financial intermediation from regulated banks to emerging fintech shadow banks, some of which may have global reach. These developments, and the diffusion of cryptocurrencies promising anonymized payment systems may hinder the effectiveness of monetary policy, and eventually induce greater financial instability. States may encourage the diffusion of efficient financial intermediation in ways that benefit users, while restricting the use of anonymized exchange and global monies to reduce the threat of a shrinking tax base, and to maintain financial stability.
\end{abstract}

Joshua Aizenman

Economics and SIR

USC

University Park

Los Angeles, CA 90089-0043

and NBER

aizenman@usc.edu 


\section{Overview and summary}

This paper takes stock of the recent challenges facing Emerging Market Economies in the post Global Financial Crisis (GFC) environment. The pre-GFC environment was shaped by the confluence of four key developments.

First, financial globalization and de-regulation, a process that started in the late 1970s in the OECD countries and was followed by Emerging Markets in the 1990s-2000s, transformed the global financial system into a complex cobweb of global networks, exposing countries to financial shocks transmitted by volatile bursts of capital inflows and outflows of 'hot money.'

Second, despite the emergence of the Eurozone and China as large hubs of economic activity approaching the real size of the US, the US Dollar has retained, and even increased its global financial dominance. Somehow paradoxically, a crisis that started in the US in 2007-2008, ended up solidifying and even deepening the global dominance of the US Dollar. Remarkably, as the global real GDP share of emerging market economies is approaching half [adjusted for PPP issues], and the US global share declines towards fifth and below, the US Dollar's global-financial importance approaches two-thirds in 2019. ${ }^{1}$ Figure 1 reports the USD share of official reserves, showing vividly the drop following the end of the Bretton Woods system from about $85 \%$ in the early 1970 s, to about $46 \%$ in 1991 , then reversing, reaching about $70 \%$ at the birth of the Eurozone, 1999 and then gently sliding to $62 \%$ by 2019 [see Gourinchas, Rey, and Sauzet (2019), Gopinath et al. (2019)].

Third, the QE policies triggered by the GFC and the Euro Crisis pushed the nominal policy interest rate of most OECD countries toward the zero lower bound and in some, below zero. In tandem, the 'risk free' real interest rate kept with its secular trend towards zero and below. This trend started in the mid-1980s and is well exemplified by the 3-Month interest rate in the US and Germany during 20092019 [Figure $2 \mathrm{a}$ and $2 \mathrm{~b}$ ]. In 2019, more than $1 / 4$ of global bonds offer negative yield. These developments induced spells of 'search for yield', exposing the Emerging Market Economies to large and volatile financial flows [figure 2c], increasing down the road the OECD demand for local currency debt in most emerging markets, and intensifying the application of macro-prudential tools aiming at greater financial stability by Emerging Market Economies (EMs).

\footnotetext{
${ }^{1}$ Countries making up 70\% of global GDP use the US Dollar as an anchor currency, and about half of global trade is invoiced in Dollar. As of March 2018, $73.5 \%$ of the international credit to nonresidents was US \$ denominated, followed by $24 \%$ euro dominated [sources: BIS Quarterly Review, September 2018, Carney (2019)].
} 
Finally, the acceleration of financial innovation integrating with the IT revolution [fintech] on a global scale, and the growing globalization of finance imposes new and escalating challenges for regulators aiming to secure financial stability and fight the black and informal economy.

These developments validated the importance of precautionary policies adopted by emerging markets after the wave of sudden stop crises in the 1990s, but also put to the fore new policies, and increased emerging markets' will to experiment with new defensive measures. Below is a summary of the main points advanced in this paper:

I. Emerging markets increased the use of inflation targeting (IT), a regime that showed its resilience over the past 20 years. By 2018, 23 countries used IT de jure, of which 18 adopted it by 2002. About half of these countries are Emerging Markets [see Figure 5]. With the ECB, the number of countries living with currency following the IT regime is much larger. In addition, a growing number of countries are de-facto following a hybrid version of inflation targeting. A significant share of emerging markets under IT, dominated by commodity countries, adjust the policy interest rate as part of a broader policy of IT and real exchange rate management. Under these circumstances, the policy interest rate is also impacted by real the exchange rate and international reserves (IR) changes.

II. Inflation targeting works well with independent central banks. Yet, fiscal dominance concerns may hinder the efficacy of central banks. This suggests experimenting with the integration of monetary rules - like IT - with fiscal rules, possibly linking these rules with the operations of buffers like IR and Sovereign Wealth Funds (SWF). The GFC validated the benefits of counter-cyclical management of IR and SWFs in the context of stabilizing the real exchange rate. Buffer policies may also benefit from applying macro-prudential regulations aimed at managing the balance sheet exposure of the financial system to foreign currency debt, and mitigating the risk of sudden-stops and capital flight.

III. A growing share of EMs experiment with the application of financial technologies (fintech) as part of their adaptation to the information technology revolution. The growing fintech diffusion changes profoundly the use of cash, transfer payments, and the nature of financial intermediation. Fintech's major impact has been the massive scaling up and consolidation of financial services, approaching the 'winner takes (almost) all' syndrome. In principle, national boarders do not bound the scaling dynamics associated with fintech. Yet, the nation states may, at a cost, limit this scaling.

The Fintech revolution imposes growing pressure on traditional banks, providing consumers with the promise of cheaper and faster financial services. Yet, these developments may also hinder the effectiveness of monetary policy, and reduce the tax base. Finding the proper regulatory response to 
fintech's impact on monetary policy transmission and on the tax base is a work in progress. While the Nation State may focuse on retaining control of financial stability and its tax base, the fintech sector is mostly aiming at rent maximization, overlooking possible adverse externalities associated with its activities. Thereby, we may witness an accelerated arms race between the state and the fintech sector. IV. An example of these forces is the advance of cryptocurrencies, promising anonymized financial intermediation. In contrast to the success of inflation-targeting regimes, there is no feasible path towards stability of a decentralized currency. This instability reflects the tragedy of the commons associated with cryptocurrencies - the public good aspect of stable valuation conflicts with the possible interests of 'whales' (the large holders of the currency that may benefit from endogenous volatility). Chances are that most nation states will aim at containing these activities to a small-scale niche of finance. The nation state may ignore niche financial innovations, but will regulate or even 'nationalize' them once their size and instability become a systemic threat. Thereby efficient scalability of a successful decentralized currency will survive as long as the private sector coordinates its policies with the nation state. States may opt to follow a dual goal of encouraging the diffusion of efficient financial intermediation in ways that benefit consumers, while restricting anonymized financial intermediation and global monies in ways that minimize the threat of a shrinking tax base, and maintain the state's ability to support financial stability.

\section{EMs in the past decades - Brave New World?}

The short history of macroeconomics during the 21 th century is a humbling experience to policy makers, scholars, and practitioners. The buoyant assessment of the state of macroeconomics was summarized by Professor Lucas, stating in his AEA address, Macroeconomic Priorities, 2003: "Macroeconomics in this original sense has succeeded: Its central problem of depression prevention has been solved, for all practical purposes, and has in fact been solved for many decades. ... The potential gains from improved stabilization policies are on the order of hundredths of a percent of consumption."

At the dawn of the $21^{\text {st }}$ century, the US Federal Reserve (the Fed) was credited by a growing share of economists with contributing to the 'Great Moderation' associated with the large decline in the volatility of key macroeconomic indicators and lower risk premia. The Great Moderation period mostly overlapped the tenure of Alan Greenspan, heading the Fed from 1987-2006. His views gained prominence, and captured well the zeitgeist in the late 1990s and early 2000s - growing optimism in the stabilizing effect of market forces and the ability of the US Federal Reserve to deal with adverse tail risk events, the importance of financial liberalization, and viewing regulations as cumbersome and 
ineffective: "As we move into a new century, the market-stabilizing private regulatory force should gradually displace many cumbersome, increasingly ineffective government structures." (Alan Greenspan, Fed Chair, April 12, 1997). Accordingly, bubbles are impossible to detect ex ante, easier to clean ex-post. $^{2}$ Governor Bernanke, the Fed Chair that replaced Chair Greenspan from 2006, attributed in 2004 the Great Moderation to improved monetary policy, including the adaptation of the Taylor rule. ${ }^{3}$

Notable exceptions to these buoyant views included Robert Shiller, warning in the early 2000s that the bubbly dynamics migrated from the 'dot com' technology sector in the late 1990s to the housing market. Rajan (2005) asserted that growing endogenous exposure to under-valued tail risk developments in the financial sector led to an expansion in its ability to spread risks, thereby creating much greater access to finance for firms and households. He attributed this to the emergence of a whole range of intermediaries ['shadow banking'], whose size and appetite for risk may expand over the business cycle. These intermediaries can also leave themselves exposed to certain small probability risks that their own collective behavior makes more likely. Applying principle-agent arguments, and distance-from-default analysis, he attributed these trends to the financial liberalization and banking deregulation process that took off from the 1980s, concluding that the US economy became more exposed to financial-sector-induced turmoil than in the past.

The GFC validated Rajan (2005)'s conjectures, challenging Greenspan's assertion that 'bubbles are impossible to detect ex ante, easier to clean ex-post.' Specifically, Jordà et al (2015) concluded that history shows that not all bubbles are alike. Some have enormous costs for the economy, while others blow over. They also demonstrate that what makes some bubbles more dangerous than others is credit. When fueled by credit booms, asset price bubbles increase financial crisis risks; upon collapse they tend to be followed by deeper recessions and slower recoveries. Credit-financed housing price bubbles have

\footnotetext{
2 "It was far from obvious that bubbles, even if identified early, could be preempted short of the central bank inducing a substantial contraction in economic activity--the very outcome we would be seeking to avoid."

..."Instead, we noted the need to focus on policies "to mitigate the fallout when it occurs and, hopefully, ease the transition to the next expansion." Alan Greenspan, Fed Chair, April 12, 1997 August 30, 2002. https://www.bis.org/review/r020905a.pdf

3 "The finding that monetary policymakers violated the Taylor principle during the 1970s but satisfied the principle in the past two decades would be consistent with a reduced incidence of destabilizing expectational shocks." ..."The Great Moderation, the substantial decline in macroeconomic volatility over the past twenty years, is a striking economic development. ...I have argued today that improved monetary policy has likely made an important contribution not only to the reduced volatility of inflation (which is not particularly controversial) but to the reduced volatility of output as well." Governor Bernanke, The meetings of the Eastern Economic Association, Washington, DC. February 20, 2004.
} 
emerged as a particularly dangerous phenomenon. They also showed that run away credit growth increases the odds of reaching the zone of costly financial instability. The Global Financial Crisis, 2007-2009, and the proceeding Euro Crisis, 2010-2013, were watershed events, shifting the policy and research focus in search for strategies that fit better the era of heightened volatility and interest rates approaching the zero boundary, and the growing threat of secular stagnation. The outcome has been a richer application of principal-agent, asymmetric information, behavioral and other approaches. ${ }^{4}$ In this paper, we focus selectively on current debates dealing with recent developments, occasionally in the context of these past macro contributions.

3. Emerging Markets' Trilemma Choices: From fixed exchange rate and financial autarky to IT, managed financial integration, buffered by reserve and macro-prudential regulations.

The 1960s-1970s decades induced profound changes: the collapse of the Bretton Woods (BW) regime reflected the recovery of Western Europe from WWII, and the search for global order fitting better the aspirations of the core of Europe. The greater exchange rate flexibility of key currencies, and the accelerating of financial liberalization put in motion new forces. The remarkable recovery of Japan after WWII provided a vivid example of export led economic takeoff, a process that with a lag inspired the takeoffs of South Korea, China and more than dozen of other countries forming the block of Emerging Markets (EMs). Within fifty years, the EMs became the hub of global growth, increasing their global GDP share towards half and above (adjusted by purchasing power considerations). Remarkably, in the early 1990s EMs opted to embrace greater financial integration, a trend illustrated by Mexico in the aftermath of the NAFTA agreement, as well as Korea, Thailand and others. This came at the end of the lost decades of the 1980s, a time that most EMs were exposed to the debt overhang crises generated by excessive borrowing in the 1970 s, funded by recycling the petro-dollar generated by the

\footnotetext{
${ }^{4}$ Stiglitz and Tirole are among the earlier contributors in this domain, mostly overlooked by policy makers in the late 1990s and early 2000s. There has also been a growing recognition of the need to refresh past macro paradigms, including Mundell-Fleming's Trilemma, Triffin's paradox, the zero lower boundary challenges, the paradox of thrift, the redundancy problem (aka the $n-1$ problem); the inequality of the number of policy instruments and the number of targets at the international level, suggested by Mundell (1969), an example of Tinbergen's (1952) analysis of targets and instruments, and other mostly overlooked concepts.
} 
quadrupling of the price of oil in the early 1970s. The renewed hard currency borrowing of EMs in the early 1990s, still operating mostly under fixed exchange rate promoted a brief 'honeymoon' with upbeat assessments of Mexico, Korea and other EMs. These development, however, set the stage for new types of banking and balance of payment crises.

Mexico's history illustrated the hazard of EMs attempts to keep pegging their currency at times of greater financial integration, while maintain proactive monetary policy. Simply put, this configuration was contradicting the Mundell-Fleming trilemma, putting in motion forces that induced the full-blown Tequila Crisis of December 1994. Intriguingly, Mexico adopted a flexible exchange rate regime after the crisis, while increasing its financial integration over time. The crisis also came at a time when the choice for deeper financial integration was viewed as a way to encourage the continuation of FDI inflows into Mexico triggered by NAFTA, viewing this trend as the key for Mexico's future. The Mexican crisis of 1994 turned out to be the first in a wave of more than a dozen similar crises, the most notables being the East Asian, the Russian and the Brazilian crises during the second half of the 1990s [see Eichengreen (2019)].

A common script of the dynamics leading to these crises was greater external borrowing in hard currencies induced by greater financial integration, economic boom inducing real exchange rate appreciation and current account deterioration pressures. The ensuing economic boom was frequently terminated within several years by incipient capital flight triggered by concerns about dwindling international reserves. Calvo (1988) dubbed these crises as 'Sudden Stop Crises,' where the sudden stop of external funding induce exchange rate, balance of payment and banking crises. Most of the affected countries followed similar adjustment, moving over time towards the middle ground of MundellFleming Trilemma: controlled exchange rate flexibility, growing but controlled financial openness, and viable though limited monetary independence, supported by hoarding and managing growing buffers of international reserves. ${ }^{5}$ This trend was much more pronounced in high saving rate countries in East Asia, induced by 'precautionary motives' aimed at reducing the probably and the damages of sudden stop crises. Arguably, some of this trend reflected 'mercantilism' - the proactive policy of delaying the real appreciation associated with a successful manufacturing export led growth strategy, exemplified by

\footnotetext{
${ }^{5}$ Arguably, this trend reflected the recognition that flexible exchange rates among key global currencies in the post BW world [USD, DM, BP, YEN] exposes EMs to greater implicit exchange rate flexibility, as pegging to one of these currencies implies floating against the others. The sudden stop crises induced also precautionary hoarding of international reserves, and EMs economies tripled their international reserves/GDP in a decade, from about $8 \%$ in the early 1990 s to about $30 \%$ in early 2000s [Aizenman and Lee (2007)].
} 
China. Observers also noted the possibility of competitive hoarding by affected countries, aiming at protecting market shares, and 'keeping with the Joneses' dynamics [Cheung and Qian (2009)]. The empirical research overviewed by Aizenman (2019) validated the emergence of a continuous version of the Trilemma, where most emerging markets converged to the middle ground of the trilemma. Yet, the original Trilemma was modified in several other important ways.

First, financial stability was added as a key policy goal, morphing the Trilemma into possible Quadrilemma. While financial stability was an implicit goal during the Bretton Woods system, the tight controls of capital flows (mostly prohibited, with few exceptions needing the state's approval) implies limited exposure to financial fragility due to external factors. The overall tight regulation of banks, an outcome of the Great Depression era, limited leverage and risk taking by domestic banks, taming exposure to domestic financial fragility. The Sudden Stop crises of the 1990s vividly illustrated the cost of greater financial integration and hard currency external borrowing, in the form of growing susceptibility to capital flight crises associated with real depreciations, inducing sharp increases in the real cost of serving the external, hard currency debt, destabilizing the domestic banking system, and inducing occasional costly sovereign defaults, banking crises, and restructuring.

Second, the increasing global share of GDP coming out of the Eurozone and EMs, along with the Global Financial Crisis of 2007-2009 and the following Eurozone crisis, led to the paradoxical trend of increasing the global role of the US Dollar as the dominant currency of invoicing international trade, supplying about $2 / 3$ of international reserves and the deepest and most liquid market of 'safe assets', all at a time that the Global GDP share of the US declined and reached parity with the Eurozone and China [adjustment by PPP]. These developments and the GFC led Rey (2013) to conjecture that the Trilemma morphed in past decades into a dilemma. Specifically, independently of exchange rate regime choices, countries adopting open capital markets are exposed to the global financial cycle, a cycle dominated by US monetary and financial policies, substantially weakening their monetary independence. The only effective way to regain monetary independence in Rey's dilemma world is by shutting down financial integration, controlling heavily private flows, and prohibiting flows deemed too destabilizing.

The ongoing debate propagated by the dilemma conjecture outlined several challenges to Rey's view. While the financial importance of the US dollar and US monetary policies increased, exchange rate regimes still matter in the presence of balance sheet exposure associated with external borrowing in hard currency. With proper management of financial policies, exchange rate flexibility provides at the margin greater monetary autonomy, though the actual Trilemma trade-offs have been affected by the GFC and the changing conduct of monetary policies amidst the challenges of QE and policy interest 
rates approaching the zero lower bound, thereby increasing the global importance of the US financial and real cycles. Taking this perspective, Aizenman, Chinn, and Ito (2016) examine how the movements in the center economies - the U.S., Japan, the Eurozone, and China — affect the Trilemma choices and financial conditions of developing and EMs countries (dubbed peripheral countries). In 2000s-2010s, the strength of the links with the center economies have been the dominant factor. The movements of the policy interest rate also appear sensitive to global financial shocks around the EMs' crises of the late 1990s, and since the 2008 GFC. The exchange rate regime and financial openness are found to have a direct influence on the sensitivity to the center economies. The weights of major currencies, external debt, and currency debt compositions are significant factors. ${ }^{6}$

An insightful analysis by Klein and Shambaugh (2015) studies whether partial capital controls and limited exchange-rate flexibility allow for full monetary policy autonomy. They find that partial capital controls do not generally allow for greater monetary control more than open capital accounts, unless capital controls are quite extensive. However, a moderate amount of exchange rate flexibility does allow for some degree of monetary autonomy, especially in emerging and developing economies. Empirically, they observe that while some countries have long-standing, pervasive capital controls, a substantial subset of countries use limited controls on an episodic basis. ${ }^{7}$ In this context, Obstfeld, Ostry, and Qureshi (2019) find that countries with fixed exchange-rate regimes are more likely to experience financial vulnerabilities - faster domestic credit and house price growth, and increases in bank leverage - than those with relatively flexible regimes. The transmission of global financial shocks is likewise magnified under fixed exchange-rate regimes relative to more flexible (though not necessarily fully flexible) regimes. The authors attribute this to both reduced monetary policy autonomy and a greater sensitivity of capital flows to changes in global conditions under fixed rate regimes.

Among the important developments impacting the conduct of monetary policy has been the emergence of inflation targeting (IT) as the new paradigm of monetary policy. The curious history of IT goes back to New Zealand (NZ) in the early 1990s, reviewed by Archer (2000). The NZ emerging IT

\footnotetext{
${ }^{6}$ More specifically, having a higher weight on the dollar (or the euro) makes the response of financial variables more sensitive to a change in key variables in the U.S. (or the euro area, respectively), such as policy interest rates, exchange rate market pressure, and the real exchange rate. Thus, the degree of exchange rate flexibility continues to affect the sensitivity of developing countries to policy changes and shocks in the center economies.

7 Their results are in line with Klein (2012), who classified capital control of these regimes into "walls" and "gates," respectively, and shows that walls are more effective than gates in limiting asset price booms and swings in the value of the real exchange rate. In addition, in any given year, there is a wide range of scope with which capital controls are employed, generating an extensive middle ground between open and closed capital markets.
} 
regime has been based on 4 pillars: the inflation rate is the medium term objective for monetary policy; the medium-term objective is implemented using a tightly specified inflation target; a clear institutional structure, typically independent CB; and heavy reliance on transparency is supporting the IT arrangement. Figure 5 portrays the remarkable time line of the global diffusion of IT. By now there are 23 countries that de jure adopted IT, of which 18 adopted it by 2002. More than half of the IT countries are Emerging [or ex emerging] Market Economies. With the ECB following a rule akin to IT, the number of countries living under a de-jure regime is approaching $40 .{ }^{8}$ The IT regime gained momentum in tandem with the growing popularity and adoption of the Taylor Rule. ${ }^{9}$

This remarkable yet short history of IT led Rose (2007, JIMF) to declare "A Stable International Monetary System Emerges: Inflation Targeting is Bretton Woods, Reversed." Accordingly, "A stable international monetary system has emerged since the early 1990s. A large number of industrial and a growing number of developing countries now have domestic inflation targets administered by independent and transparent central banks. These countries place few restrictions on capital mobility and allow their exchange rates to float. The domestic focus of monetary policy in these countries does not have any obvious international cost. Inflation targeters have lower exchange rate volatility and less frequent "sudden stops" of capital flows than similar countries that do not target inflation. Inflation targeting countries also do not have current accounts or international reserves that look different from other countries. This system was not planned and does not rely on international coordination. There is no role for a center country, the IMF, or gold. It is durable; in contrast to other monetary regimes, no country has been forced to abandon an inflation-targeting regime. Succinctly, it is the diametric opposite of the post-war system; Bretton Woods, reversed."

This characterization of the successful diffusion of inflation targeting was an insightful snapshot of the state of IT prior to the GFC. Yet, IT is not a panacea, and the GFC triggered debate about the effectiveness and desirability of IT of the Taylor Rule type. Critiques noted that a growing share of OECD countries, including the US, Japan, and the Eurozone are undershooting their targets. This

\footnotetext{
${ }^{8}$ The euro "The primary objective of the ECB's monetary policy is to maintain price stability. The ECB aims at inflation rates of below, but close to, $2 \%$ over the medium term." https://www.ecb.europa.eu/mopo/html/index.en.html.

${ }^{9}$ Taylor's rule was estimated for the Paul Volcker disinflation, 1984-1992 [Taylor (1993)], as a linear policy rule adjusting the policy interest rate to the evolving inflation gap and the output gap. A key result of the calibration is that the semi elasticity of the policy interest rate with respect to inflation shock is about 1.5 , significantly above 1 (i.e. the way to deal with an inflationary shock is to increase the real interest rate by about half of the inflationary shock).
} 
observation, and the collapse of the US policy interest rate towards zero and into the negative domain across several European countries in the aftermath of the GFC, led to the concern that IT may be too conservative of a rule, overlooking the challenges associated with debt deflation and zero boundary concerns. Specifically, Blanchard (2010) and Krugman (2012) advocated that central banks announce a higher inflation target, around $4 \%$ or $5 \%$, raising the possibility of increasing the target in turbulent times, and considering alternative rules like price level targeting that will compensate periods of inflation below the target with periods of tolerating overshooting the target, as well as other ideas. ${ }^{10}$

Another concern has been that in the aftermath of the GFC, growing share of central banks are losing their independence. Furthermore, some of the de jure IT countries follow policies that differ sharply from the original ' 4 pillars' NZ variety, to a degree that the targeted inflation is losing its credibility and relevance, as the country approaches the 'collapsing regime' syndrome. Examples of this trend include the recent history of Turkey and Argentina. The case of Turkey illustrates vividly the hazard of losing CB independence, and the de-anchoring of inflation that may follow fiscal dominance. ${ }^{11}$ To recall, the distinction between fiscal and monetary dominance regimes is due to Sargent and Wallace (1981). If the government adjusts the primary deficit to limit debt accumulation, the central bank is not forced to inflate away the debt, allowing the central bank to focus on inflation targeting, in line with monetary dominance. Long periods of large fiscal deficits and high public debt-to-GDP ratios raise concerns over growing fiscal dominance by heightening the links between fiscal policy, monetary policy and government debt management. This may be the case when higher policy interest rates or depreciating currencies raise concerns about debt sustainability, limiting monetary independence. Possible manifestations of these concerns include the 'fear of floating,' fiscal pressure to mitigate rises of policy interest rates, financial repression, and the like. The fiscal dominance argument may apply both for hard currency public and private debt [Ahmed, Aizenman, Jinjarak (2019)]. ${ }^{12}$ In the case of

\footnotetext{
${ }^{10}$ See Inflation targeting is dead: Long live nominal GDP targeting Jeffrey Frankel 19 June 2012.

${ }^{11}$ As of August 2019, the Turkish CB stated a target of 5\% from 2012. This targeted was missed significantly, and inflation accelerated non-linearly during that time from $10 \%$ in 2012 to $20 \%$ in 2018 . See http://www.tcmb.gov.tr/wps/wcm/connect/EN/TCMB+EN/Main+Menu/Core+Functions/Monetary+Policy/PRIC E+STABILITY+AND+INFLATION/Inflation+Targets.

${ }^{12}$ Ahmed et al. (2019) reports that higher ratios of public debt-to-GDP are associated with lower policy interest rates in advanced Economies. In EMs under non-IT regimes, composed mostly of exchange rate targeters, the interest rate effect of higher public debt is non-linear and depends both on the ratio of foreign-currency to total public debt, and on the ratio of hard-currency debt to GDP. For these EMs under non-IT regimes, real exchange rate depreciation and international reserves accumulation are significantly associated with higher interest rates.
} 
large private debt exposure, stabilizing the real exchange rate by large sales of international reserves (IR) needed to fund servicing the private debt may prevent a banking and financial crisis, a crisis that may induce the socialization of private losses, as has been the case in Ireland and Spain during the Eurozone crisis.

Countries exposed to a large net hard currency external debt face an open economy version fiscal dominance, in the form 'fear of floating' [Calvo \& Reinhart (2002)]. Specifically, real exchange rate depreciation increases the costs of serving their external debt by the external debt/GDP times the depreciation rate (the cost measured as a fraction of the country's GDP). Under these circumstances, the Central Bank may put higher weight on stabilizing the real exchange rate to reduce the cost of serving the external debt, and may limit the increase of the policy interest rate, hoping to delay a recession and adjustment. While this 'gambling for resurrection' policy may provide some policy space in the short run, it may backfire overtime.

In principle, successful management of IR and the exchange rate in the context of large debt overhang is possible, as long as the CB is committed to follow the necessary counter-cyclical buffers and regulatory policy consistently over the business cycle. For example, consider the Central Bank of Russia's [aka CBR] management of their commodity-intensive economy during 2000-2019. CBR hoarded large portions of the hard currency oil revenue when Russia's terms of trade improved during the oil price rise prior to the GFC, from about $40 \$ /$ barrel in 2000 to about $140 \$ /$ barrel in 2008 . About $1 / 3$ of these reserves were used to stabilize the real exchange rate when the price of oil subsequently collapsed. This policy of hoarding reserves for stormy days and selling reserves at times of collapsing oil revenue mitigated the Russian real exchange rate's appreciation at times of rising oil prices, and probably prevented a full blown Russia banking and financial crisis following the drop of oil prices [Aizenman and Jinjarak (2019)].

Arguably, the successful international reserves buffer management of Russia during 2000-2019 is a second-best policy. The first-best policy may include macro prudential regulations and possibly external borrowing taxes scaling down the balance sheet exposure of Russia by raising the costs of borrowing in good times. Proper application of these policies may reduce the need for large hoarding to support the bailouts of systemic borrowers in bad times (Rodrik (2006)). Political economy

EMs with high commodity exposure show the most persuasive evidence of debt levels influencing policy interest rates. 
considerations suggest that the Russian central bank, probably operating with limited ability to impose macro prudential regulations on powerful insiders, may be credited for saving Russia in the 2000s-2010s from a much costlier exposure to sudden stops of the 1998 Russian crisis variety. In contrast, Turkey in the 2010s did not adopt systematic buffering policy, at its own peril. See Kalemli-Özcan (2019) for critical assessment of EMs capacities to deal with international spillover effects of US policies, and Alfaro et al. (2008) for the key importance of the quality of institutions in stabilizing the patterns of capital flows and the credibility for implementing desirable macroprudential policies.

Asian countries have made significant use of macroprudential tools, especially housing-related measures. Zhang and Zoli (2016) found that housing-related macroprudential policies, particularly loanto-value ratio caps and housing tax measures, have helped curb housing price growth, credit growth, and bank leverage in Asia. ${ }^{13}$ Aizenman, Jinjarak and Zheng (2019) found that, although house price appreciations are positively associated with output growth, house price depreciations may either undermine or stimulate growth, depending on the depth of correction and the market environment. Large house price depreciations are associated with strong recovery in growth in the absence of banking crises, and this association is stronger in countries with a relatively weak safety net. ${ }^{14}$ Thereby, regulations reducing the risk of banking crisis during periodic corrections of the real estate market are associated, on average, with higher and more stable growth rate. Macro-prudential policies also mitigate growing balance sheet exposures associated with greater volatile flows of "hot money" in the aftermath of the GFC [Cerutti, Claessens, \& Laeven, (2015); Korinek, (2011); Ostry (2012); Shin (2011)]. ${ }^{15}$

\footnotetext{
${ }^{13}$ Similar results were reported in other regions [Vandenbussche, J., Vogel, U., \& Detragiache, E. (2015)].

${ }^{14}$ These results are consistent with the conjecture that delaying adjustment to large valuation losses induces deeper and more prolonged stagnation. Faster realization of losses combined with income support that deals with poverty mitigation may be superior to adjustment delays. The association between house price depreciations and economic growth is also affected by the legal system and personal bankruptcy laws, and the prevalence of mortgage insurance.

${ }^{15}$ Aizenman et al. (2017) finds that a more extensive implementation of macroprudential policies would lead EMs to regain greater monetary independence from Center Economies [US, EZ, Japan] when the Center Economies implement expansionary monetary policy; when EMs run current account deficit; when they hold lower levels of international reserves; when their financial markets are relatively closed; when they are experiencing an increase in net portfolio flows; and when they are experiencing credit expansion. Macroprudential policies negatively affect the interest rate connectivity between the Center Economies and the EMs especially in periods when the CEs implement expansionary monetary policy. The results also suggest that macroprudential policies and IR holding are substitutes, in line with Rodrik (2006).
} 
While the original inflation targeting and Taylor Rule ignored the real exchange rate as a policy goal in OECD countries, the research dealing with Emerging Market Economies put it to the fore [Aizenman, Hutchison, Noy (2011); Berganza, Carlos, Broto (2012); Ghosh, Ostry, Chamon (2016), Ahmed, Aizenman, Jinjarak (2019)]. Indeed, exchange rate targeting (aka exchange rate stabilization) may be accomplished by putting higher policy weight on stabilizing the real exchange rate, possibly by proactive management of sizable buffers of international reserves (IR) and sovereign wealth funds (SWFs). Concerns about fiscal dominance led to augmenting IT rules with fiscal rules. Chile and Norway provide vivid examples of possible benefits associated with such rules, helping to reduce the pro-cyclicality of fiscal policy, and providing greater fiscal and monetary spaces [Frankel, Vegh, and Vuletin (2014)]. Time will tell to what degree other countries with more limited institutional capacities and policy stability will follow thorough similar policies.

\section{Fintech Diffusion, Financial Intermediation, and the Future Role of Central Banks and Regulators - Work in Progress or Regress?}

A growing share of Emerging Markets experiment with fintech innovations. The diffusion of fintech changes profoundly the use of cash, transfer payments, and the nature of financial intermediation. Fintech may be especially attractive in emerging markets as it allows countries with limited and inefficient banking services to leapfrog into the $21^{\text {st }}$ century, utilizing the penetration of cell phone services in countries that were historically constrained by limited phone line services. The benefits of financial inventions are exemplified in the IMF WB report "Fintech: The Experience so Far", June 2019. The report highlights include "Asia is ahead of other regions in many aspects of fintech. In China, the massive scale of its markets and a regulatory "light touch" in the early years supported fintech development, with China emerging as a global leader. In India, large-scale adoption of mobile payments and an increase in money transfers have driven growth in mobile payments... Sub-Saharan Africa is a global leader in mobile money innovation, adoption, and usage. The region leads the world in mobile money accounts per capita (both registered and active accounts), mobile money outlets, and volume of mobile money transactions. In Africa, close to 10 percent of GDP in transactions are occurring through mobile money, compared with just 7 percent of GDP in Asia and less than 2 percent of GDP in other regions. Across Africa, the adoption and use of technology in the provision of financial services is changing the way in which financial service providers operate and deliver products and services to their customers." 
While some view the wave of fintech as the path to a brave new world, supplying cheaper and faster financial services, fintech comes also with its disruptive forces. Fintech's easier scalability has induced consolidation of financial services, approaching the 'winner takes (almost) all' syndrome. In principle, national boarders do not bound fintech scaling dynamics. Yet, nation states may, at a cost, limit this scaling. Deeper fintech diffusion may redirect financial intermediation from regulated banks into emerging fintech 'shadow intermediaries,' some of which may have global reach. Fintech's disruptive power leads also to complex agency problems, where the growing market clout of fewer dominant suppliers aiming at profit maximization may come at growing social costs.

To put fintech disruptive effects in the proper context, note that history is loaded with innovations with double-edged features. The diffusion of phone networks via costly land lines during the $20^{\text {th }}$ century induced powerful network externalities, leading to the emergence of 'natural monopolies.' 16 The benefits of fast and reliable communication provided by a few suppliers induced regulators to view phone companies as 'utilities', regulating their pricing and mergers and acquisitions. Oil and coal provide plentiful cheap energy, but lead to environmental degradation, polluted air, and accelerated climate change. A common feature across these examples is that scalability leads frequently to externalities, and requires the proper policies to curb such forces unleashed by scalability. ${ }^{17}$ These concerns led Rajan and Zingallas (2003) to warn about the gloomier side of under-regulated capitalism; "Saving Capitalism from the Capitalists."18

${ }^{16}$ The percentage of housing units with telephones in the US in 1920 was $35 \%$, reaching $78 \%$ in 1960 , and $95 \%$ by 1990 [source: Federal Communications Commission].

${ }^{17}$ With Bitcoin, the analogy of Fintech's social effects to energy's pollution is by now a reality: In 9/2019, Bitcoin's capitalization was $\$ 182$ Billion, about $0.2 \%$ of global GDP, at times that managing Bitcoin transactions consumed $0.3 \%$ of global electricity. This probably explains the Chinese authority declaration of 4/2019, "Bitcoin is Wasteful Activity" [see https:/www.wired.com/story/china-says-bitcoin-wasteful-wants-ban-mining/, and https://thenextweb.com/hardfork/2019/09/07/satoshi-nakaboto-bitcoin-whale-moves-1b-worth-of-bitcoin-for-just700-in-fees/ accessed 9/2019].

${ }^{18}$ They note that capitalist economic order is praised frequently for its efficiency. Yet this efficiency holds as long as competitive forces dominates, and powerful agents do not use their economic clout to bend the rules of the game in favor of their narrow benefits, induced what some dubbed 'crony capitalism.' Under-regulated large corporations have no interest in the creation of a modern and flexible financial system with free entry of competitors, as that would provide opportunities for newcomers to challenge the incumbent dominance. Left to its own devices, a market dominated by powerful corporations is not self-regulated, and maintaining efficiency needs government regulation. This is not without risk either, as insider corporations have the incentives to invest in capturing and keeping governments in their service, suppressing the market. Therefore, securing the full advantages of capitalism requires the right balance of regulations enacted by governments that are not captured by narrow corporate interests. 
Financial innovations provide growing benefits to underserved populations, at low costs and improving efficiency. Yet, the growing market clout of a few global giant suppliers of IT and fintech services may induce them to compromise privacy as part of their business model. The data gathered by the suppliers of financial and commercial services relying on scalable IT services becomes a traded commodity. ${ }^{19}$ While the benefits of cheaper, faster financial services are frontloaded, the possible costs of diluting existing regulatory capabilities of the nation state are lurking, increasing the exposure to more disruptive tail risks and financial instability [see Ragan (2005)]. The arrival of cryptocurrencies promising anonymized liquidity services further up the ante. Scalable cryptocurrencies may hinder the effectiveness of monetary policy, channeling financial intermediation into shadowy networks facilitating tax dodging. Finding the proper regulatory response to fintech's impact on monetary policy transmission and on the tax base is a work in progress.

While nation states have focus after the GFC on financial stability and securing the tax base, the fintech sector is mostly aiming for rent maximization, with little regard to possible adverse externalities associated with these activities. Thereby, we may witness an accelerated arms race between the state and the fintech sector. Putting this arms race in the public finance perspective, financial stability is a public good providing the infrastructure supporting faster growth. This public good aspect may be overlooked by financial innovators. Thus, an under-regulated fintech sector leads to moral hazard financial instability increases the odds of costly financial crises. As the GFC illustrated, at a time of peril private sector losses are socialized, even by governments that championed prior to the crisis 'no bailouts. $^{20}$

The growing number of cryptocurrencies illustrates the large private demand for anonymized, decentralized financial innovations. The history of cryptocurrencies goes back to the mission statement

\footnotetext{
${ }^{19}$ It may also open the door for predatory states to engage in 'social engineering' fed by big data providing real time feedback, possibly in the form of 'social score' and the like.

${ }^{20}$ The bailing out by 'market-friendly governments' is not an accident - the modern US more than quintupled the average Federal tax/GDP in comparison to the tax burden in the era of Free Banking (1837-1862) and National Banking (1938-1913). In exchange, the taxpayer expects the state to provide financial and economic stability, frequently punishing administrations that overlook the need to stabilize the economy at times of peril. This modern social contract is the outcome of evolutionary forces that induced the US to converge from the Free and National Banking eras and the absence of federal level regulations of the $19^{\text {th }}$ century to the 'New Deal' era that emerged after the Great Depression. A key example of this evaluation is the formation of the FDIC 1933, Federal Deposit Insurance, "backed by the full faith and credit of the United States," (i.e., backed by the tax payer), ultimately relegating to the Treasury and the Federal Reserve the task of securing financial stability.
} 
of the bitcoin, promising "Bitcoin: A Peer-to-Peer Electronic Cash System" [Nakamoto (2008)]. ${ }^{21}$ With a short lag, this paper inspired growing trade in the 'electronic cash' Bitcoin. The volume, and price history of Bitcoin is plotted in Figure 6. Notable is the high volatility, and the positive co-movements of prices and volume. Similar features are shared by other cryptocurrencies. This price volatility has intensified the debates about the stability problems of decentralized currencies. ${ }^{22}$ Believers argue that smarter software managing future cryptocurrencies will solve these issues, and that it is only a matter of time until a stable, decentralized currency emerges. Accordingly, inflation targeting has illustrated the viability of stable currency regimes.

But an extrapolation from inflation targeting to the feasibility of a stable cryptocurrency suffers from the fallacy of composition. Due to a systemic coordination failure, akin to the tragedy of the commons, there is no feasible path towards a global central bank that would ensure the stability of a decentralized currency. The successful diffusion of inflation targeting has shown that a nation state has the ability to stabilize the purchasing power value of its currency in terms of the country's price level. This is done by competent and relatively independent central banks. In 2019, most of global GDP is produced in IT countries. In contrast, countries that have limited the independence of their central banks have found, with a lag, that their currencies lost value. This increases the likelihood of capital flight, financial fragility and banking crises. Under inflation targeting, the national central bank has clear ownership and the duty to stabilize the national currency, using the tools under its control. It can adjust the policy interest rate to keep inflation low, manage key monetary aggregates, and communicate the central bank's policies.

In contrast, there is no clear central ownership and management of a decentralized cryptocurrency with the duty of keeping it stable, and responsibility for it. Consequently, its valuation is unstable, as gaming among various stakeholders may lead to multiple equilibria, bubbles and crashes. This instability reflects the tragedy of the commons associated with cryptocurrencies - the public good of stable valuation conflicts with the interests of anonymous large holders of the currency ('whales') who can influence its value. Whales may benefit from the endogenous instability associated

\footnotetext{
${ }^{21}$ Specifically, "A purely peer-to-peer version of electronic cash would allow online payments to be sent directly from one party to another without going through a financial institution. We propose a solution to the doublespending problem using a peer-to-peer network. The network timestamps transactions by hashing them into an ongoing chain of hash-based proof-of-work, forming a record that cannot be changed without redoing the proofof-work...".

${ }^{22}$ The analysis below expends and update the arguments outlined in Aizenman (2019) VoxEu column. See also overview of these issues in Eichengreen (2018), Roubini (2018), Cukierman (2019).
} 
with exploiting their market influence (Gandal et al. 2017). ${ }^{23}$ Instability may also reflect the multiple equilibria associated with gaming decentralized cryptocurrencies (Biais et al. 2018). Their valuations are exposed to the excessive optimism or pessimism of traders, and possible market manipulation. Cryptocurrencies do not change the rules of finance, and the agency problems that comes with financial intermediation. The anonymized nature of the exchange only magnifies these problems.

National currencies are, of course, exposed to similar speculative attacks. Yet, the clear allocation of duties to the central bank, and the bank's willingness to adopt policies for financial stability and stable currency valuation, provide the public good services associated with scalable safe currency. This is part of a complex system that may include deposit insurance schemes (akin to the FDIC), backstopped by the nation's taxpayers. Again, there is no comparable allocation of duties and 'property rights' in a decentralized currency. Therefore, one can expect relative instability to be the rule, not the exception. The combination of a decentralized currency, and anonymity associated with cryptocurrencies, makes the use of stabilizing forces, as used by large players during the era of 'National Banking' in the US, impossible. To recall, during the financial panic of 1907, J P Morgan pledged large sums of his own money, and convinced other New York bankers to do the same, to shore up the banking system. They operated as de facto lenders of last resort. The whales of that time clearly owned of the rents associated with stable financial intermediation, and so they chose to provide stabilization services as long as that would minimize their expected losses. The crisis of 1907 also illustrated the risks of private bailouts - their credibility was constrained by the balance sheets of financial institutions, and required a leader who could convince other financial whales to join the bailout. Furthermore, private bailouts reflect more the wish of whales to maximize their rents, than their concerns about households, small banks and firms, and national welfare. Indeed, the dynamics of the 1907 crisis led to the formation of the Federal Reserve System, created by the Federal Reserve Act of 1913. In contrast to the bailout coordinated by J P Morgan, the anonymity of cryptocurrency holders means there is a lack of agency, and there are no stabilizing forces of the type exhibited in the 1907 private bailout.

It is not a surprise that there is no clear path towards a global central bank with responsibility for the price stability of a decentralized currency. Among national central banks there is a reluctance to cooperate in normal times, as the mandate of each central bank prioritizes domestic goals that focus on

\footnotetext{
${ }^{23}$ In Sep. 6, 2019, the top 10 Bitcoin addresses house 5.6 percent of the total supply, the top 10014.7 percent, and the top 100034.6 percent. Source https://thenextweb.com/hardfork/2019/09/07/satoshi-nakaboto-bitcoin-whalemoves-1b-worth-of-bitcoin-for-just-700-in-fees/, accessed Sep. 8, 2019.
} 
domestic price stability, not on the global value of its currency. This coordination failure is compounded by the observation that in normal times, deeper macro cooperation among countries is associated with welfare gains akin to Harberger's second-order magnitude triangle, thus making the odds of cooperation low. When bad tail events induce imminent threats of financial collapse, the perceived losses have a first-order magnitude of terminating the total Marshallian surpluses. The apprehension of these losses in perilous times may elicit rare and beneficial macro cooperation [Aizenman (2016)]. In contrast, the anonymity of cryptocurrency owners may magnify the volatility, as there is no reason to expect the cryptocurrency's whales to provide stabilization in bad times. ${ }^{24}$ Indeed, the market clout of the Bitcoin whales provides ample opportunities to induce bubbly dynamics that may be exploited by the insiders to their own benefits. These observations are consistent with the curious correlation patterns of bitcoin valuation reported by Baur et al. (2018), noting that Bitcoin "is uncorrelated with traditional asset classes such as stocks, bonds and commodities both in normal times and in periods of financial turmoil.

The analysis of transaction data of Bitcoin accounts shows that Bitcoins are mainly used as a speculative investment and not as an alternative currency and medium of exchange."25

Taking the public finance perspective, one may conjecture that successful scalability of decentralized cryptocurrencies would breed its private failure - the nation state may ignore niche financial innovations, but would regulate or even 'nationalize' them if their size and instability became a systemic threat. Efficient scalability of a successful decentralized currency is possible as long as the private sector coordinates its policies with the nation state. Scalable financial innovations that challenge the nation state's ability to enforce law and order would trigger an 'arms race' between users and the nation state's law enforcement. A well-functioning nation state has access to deep, scalable resources. OECD countries, China and other efficient centralized regimes find ways to control scalable financial innovations. If the decentralized currency is scalable, nation states and central banks will face growing competition. They will react by either imposing regulations or reducing scalability and encryption. Either course of action crushes the emerging competition. Alternatively, they may compete directly with cryptocurrencies by offering their own e-money, as articulated by Lagarde (2018). ${ }^{26}$

\footnotetext{
${ }^{24}$ An example is the recent 'Fork Fights', see "Bitcoin Cash Hard Fork Battle: Who Is Winning the Hash War".

${ }^{25}$ The close to zero correlation of Bitcoins with other assets induced some to conclude that bitcoins may provide diversification opportunities. Without controlling for the cost of these 'opportunities,' this argument is akin to viewing casino gambling as investment in portfolio diversification.

26 “....What if, instead, central banks entered a partnership with the private sector-banks and other financial institutions - and said: you interface with the customer, you store their wealth, you offer interest, advice, loans.
} 
To put it in historical perspective, the supplier of currencies benefits access to significant resources, aka seigniorage. History provides ample examples of regimes oversupplying the means of exchange, resulting with run-away inflation. Similar dynamics may occur in weak federal system, where the states compete for greater share of seigniorage [Aizenman (1992), Cukierman et al. (1992)]. By now, most nations converged to a social contract where the state has the monopoly of supply currency, controlling the banking system and the seigniorage, and in exchange is responsible for the provision of financial stability, deposit insurance services, and a battery of regulations aiming at reaching these goals. ${ }^{27}$ The wave of Fintech of the 2010 impose clear risks on the monopoly of the state, shifting the bulk of financial intermediation to 'virtual shadow banks' associated with anonymized intermediation.

China provides an example of the feasibility and ability of the state to follow a dual goal of encouraging the diffusion of efficient fintech exchange in ways that benefits private uses and augment government's controls, ${ }^{28}$ while restricting anonymized exchange in ways that minimizes its threats to

But when it comes time to transact, we take over. This partnership could take various forms. Banks and other financial firms, including startups, could manage the digital currency. Much like banks which currently distribute cash. Or, individuals could hold regular deposits with financial firms, but transactions would ultimately get settled in digital currency between firms. Similar to what happens today, but in a split second. All nearly for free. And anytime. The advantage is clear. Your payment would be immediate, safe, cheap, and potentially semianonymous. As you wanted. And central banks would retain a sure footing in payments... Putting it another way: the central bank focuses on its comparative advantage — back-end settlement - and financial institutions and startups are free to focus on what they do best — client interface and innovation. This is public-private partnership at its best." https://www.imf.org/en/News/Articles/2018/11/13/sp111418-winds-of-change-the-case-for-new-digitalcurrency.

${ }^{27}$ Exception to these are states that chose to adopt a foreign currency as their legal tender, frequently as a mechanism to reduce past instability associated with their currency, or joined a monetary union like the Eurozone, delegating the supplying of local currency to the Central Bank of the currency area.

28 "The landscape of Chinese fintech is dominated by two players: Ant Financial, an affiliate of Alibaba, and Tencent ... Mobile transactions in China reached nearly \$18.7trn last year, 100 times more than in 2013-and more than all transactions handled worldwide by Visa and MasterCard combined. Regulators are more conflicted. By making spending easier, the fintech duo boost consumption, which has long been too low as a share of China's GDP. They bring financial services to poorer people and force state-owned behemoths to up their game. But their popularity is also an economic risk.,, "Customers are leaving banks" ... A bigger exodus might destabilise the financial system. So over the past year, regulators have put speed bumps in their way... Ant has capped the amount of cash users can invest or withdraw in a day. The online banks launched by Tencent and Antrespectively, WeBank and MYBank - have also been hindered by deposit caps. And the central bank called off a trial in which Ant and Tencent were developing credit scores on individuals. Instead, they were given stakes in Baihang, a state-owned credit-rating system. Potentially most significant is the launch in July of NetsUnion, a clearing house for online payments. Although it should make mobile payments safer, it will also stand between 
shrink the tax base, and to state's ability to control financial intermediation. ${ }^{29}$ Chances are that other states will choose their own menu of policies aiming at achieving these dual goals.

We close the section with a short overview of the Libra, introduced by Facebook in 2019. Libra's white paper provides preliminary details of the mission, and its design:

"Libra is a simple global currency and financial infrastructure that empowers billions of people.

Libra is made up of three parts that will work together to create a more inclusive financial system:

1. It is built on a secure, scalable, and reliable blockchain;

2. It is backed by a reserve of assets designed to give it intrinsic value;

3. It is governed by the independent Libra Association tasked with evolving the ecosystem..."30

fintech firms and banks, making it more difficult for Ant and Tencent to drive a hard bargain over fees... it is only a matter of time before it is used to limit mobile transactions, ostensibly to address concerns such as moneylaundering but also protecting banks from competition. All this is the backdrop for the decision by Ant and Tencent to play up technology offerings instead of financial services... The idea for both is that, with their vast user bases and data troves, they can help banks identify smaller borrowers and manage lending risks. Banks put up the capital; Ant and Tencent get "technology fees". The Economist, "Ant and Tencent As regulators circle, China's fintech giants put the emphasis on tech Sep 13th 2018."

${ }^{29}$ On September 4, 2017, Chinese Government Announcement stated: "initial coin offerings (ICOs) financing that raises so-called 'virtual currencies' such as Bitcoin and Ethereum through the irregular sale and circulation of tokens is essentially public financing without approval, which is illegal. The Announcement warned that tokens or virtual currencies involved in ICO financing are not issued by monetary authorities and therefore not mandatorilyaccepted legal tender, and thus do not have equal legal status with fiat currencies and cannot and should not be circulated and used in the market as currencies."

"As early as December 3, 2013, a notice declared banks and payment institutions in China are prohibited from dealing in bitcoins. Financial and payment institutions are prohibited from using bitcoin pricing for products or services or buying or selling bitcoins, nor can they provide direct or indirect bitcoin-related services, including registering, trading, settling, clearing, or other services" [page 106-7, "Regulation of Cryptocurrency Around the World" (PDF). Library of Congress. The Law Library of Congress, Global Legal Research Center. June 2018]. See also "Starting January 2019, non-bank payments companies must place 100 percent of their customer deposit funds under centralized, interest-free accounts as Beijing moves to rein in financial risks. In the past, third-party payments firms were allowed to hold pre-paid sums from buyers for a short period of time before transferring the money to merchants. This layout allowed companies like Alibaba's payments affiliate Ant Financial and Tencent to earn interest by depositing customer money into bank accounts." https://techcrunch.com/2019/01/17/policysqueezes-at-china-payments-firms/

${ }^{30}$ The promised stability of the future Libra is buffered by international reserves:

"What are the actual assets that will be backing each Libra coin? The actual assets will be a collection of lowvolatility assets, including bank deposits and government securities in currencies from stable and reputable central banks. As the value of Libra will be effectively linked to a basket of fiat currencies, from the point of view of any specific currency, there will be fluctuations in the value of Libra. The makeup of the reserve is designed to mitigate the likelihood and severity of these fluctuations, particularly in the negative direction (i.e., even in economic crises). To that end, the above basket has been structured with capital preservation and liquidity in 
While Libra's promised design differs from bitcoins, both share similar agency problems and concerns about their impacts on the potency of State's monetary and financial stability applies to it. First, Libra is accountable to its share-holders, with limited accountability to the actual users and the citizens of the countries exposed to its ultimate effects. A successful Libra will weaken the potency of monetary policy, dilute State's seigniorage, and may increase countries exposure to financial instability triggered by foreign shocks, like capital controls, global web disruptions, etc. Depending on the design of the future Libra, it may also shrink State's tax base. Thereby, there is no clear reason why Central Banks and Treasuries will support outsourcing financial intermediation and the payment system to a globalized private platform. The public finance logic is clear: scalable and globally successful Libra's profits are privatized, but any future losses associated with financial instability and crisis would be socialized. Consequently, States may impose clear regulations akin or more stringent than the one invoked presently on globalized financial institutions.

The list of other concerns is long -- stated reliance on the "scalable, and reliable blockchain" is speculative, as only time will tell us the convergence of blockchain into this Promised Land. Backing up the Libra with reserve accounts composed of a basket invested "in debt from stable governments with low default probability that are unlikely to experience high inflation" is exposed to serious currency valuation risks, inflationary risks, and the agency issues related to real time monitoring of the adequacy of this coverage. To illustrate, the dollar/euro exchange rate swings in the past 20 years included several spells of $25 \%$ changes in two years. Similarly, the SF/dollar experienced even larger fluctuations after the GFC. This suggests that the basket valuation will be far from stable. History illustrates that even "stable governments" occasionally impose capital controls at times of peril and crisis, and renege on past promises (see Edwards (2018)). Furthermore, the ability of private supplier of money to back its commitment is constrained by its balance sheet, as well as the will of its shareholders to do what it takes to provide the promised services. In contrast, Sovereign state's ability to support financial stability is backed by the state's ability to monetize liabilities (i.e., to print money), and to tax its citizens. In the

\footnotetext{
mind. On the capital preservation point, the association will only invest in debt from stable governments with low default probability that are unlikely to experience high inflation. In addition, the reserve has been diversified by selecting multiple governments, rather than just one, to further reduce the potential impact of such events. In terms of liquidity, the association plans to rely on short-dated securities issued by these governments, that are all traded in liquid markets that regularly accommodate daily trading volume in the tens or even hundreds of billions." Source: https://libra.org/en-US/white-paper/, accessed Sep. $3^{\text {rd }}, 2019$
} 
US, the FDIC insurance covers the US banking system, but one doubts the willingness of the US and its tax payer to support Libra's type of global arrangements. ${ }^{31}$

\section{Concluding Remarks}

The winds of trade and currency wars of recent years are vivid illustrations of the growing scarcity of global cooperation in the late 2010s, validating the need for Emerging Markets to put their house in order. The sudden stops of the 1990s, the GFC, and the EZ crisis induced Emerging Markets to adopt defensive strategies, experimenting with new policy tools. The convergence to the middle ground of the trilemma helped. Greater monetary space has been provided through the proper precautionary management of international reserves, supplemented by prudential regulations aimed at reducing the exposure to hot money inflows at times of 'risk on'; thereby mitigating the cost of hot money outflows at times of 'risk off.' Yet, these steps are not sufficient to deal with looming challenges, including a growing exposure of Emerging Markets to fiscal dominance; the need to adjust policy to fast moving endogenous fintech innovations; and to de-globalization trends. Greater application of SWFs as buffers integrated with fiscal rules may help. Experimentation with modified IT schemes and dynamic macroprudential regulations aiming at mitigating pro-cyclical leverage cycles and fintech shadow-banking may be essential to reducing Emerging Market exposure to costly future volatility. These defensive postures may be Emerging Market Economies' second-best response to the limited global international coordination.

\footnotetext{
${ }^{31}$ See Eichengreen (2019) and Niepelt (2019) for further discussion of the Libra.
} 


\section{References}

Ahmed, R., Aizenman, J., \& Jinjarak, Y. (2019). Inflation and Exchange Rate Targeting Challenges Under Fiscal Dominance (No. w25996). National Bureau of Economic Research.

Aizenman, J. (2019). On the built-in instability of cryptocurrencies, VoxEu. A modern reincarnation of Mundell-Fleming's trilemma. Economic Modelling, (81), 444-454 (2016). International coordination and precautionary policies", International Economic Journal 30(3): 379-391.

(1992). Competitive Externalities and the Optimal Seigniorage. Journal of Money, Credit \& Banking, 24(1), 61.

Aizenman, J., Chinn, M. D., \& Ito, H. (2017). Financial spillovers and macroprudential policies (No. w24105). National Bureau of Economic Research.

(2016). Monetary policy spillovers and the trilemma in the new normal: Periphery country sensitivity to core country conditions. Journal of International Money and Finance, 68, $298-330$.

Aizenman, J., Hutchison, M., Noy, I. (2011). Inflation targeting and real exchange rates in emerging markets. World Development, 39(5), 712-724.

Aizenman, J., Jinjarak, Y., \& Zheng, H. (2019). Housing Bubbles, Economic Growth, and Institutions. Open Economies Review, 1-20.

Aizenman, J., \& Lee, J. (2007). International reserves: precautionary versus mercantilist views, theory and evidence. Open Economies Review, 18(2), 191-214.

Alfaro, L., S. Kalemli-Ozcan, and V. Volosovych (2008). Why Doesn't Capital Flow from Rich to Poor Countries? An Empirical Investigation. The Review of Economics and Statistics 90 (2), 347368.

Allen, F., \& Gale, D. (2004). Competition and financial stability. Journal of money, credit and banking, 453-480.

Archer, D. J. (2000, March). Inflation Targeting in New Zealand. In IMF Institute seminar on inflation targeting.

Baur, D. G., Hong, K., \& Lee, A. D. (2018). Bitcoin: Medium of exchange or speculative assets? Journal of International Financial Markets, Institutions and Money, 54, 177-189.

Berganza, J. C., \& Broto, C. (2012). Flexible inflation targets, forex interventions and exchange rate volatility in emerging countries. Journal of International Money and Finance, 31(2), 428-444.

Biais, B., Bisiere, C., Bouvard, M., \& Casamatta, C. (2019). The blockchain folk theorem. The Review of Financial Studies, 32(5), 1662-1715.

Blanchard, O., Dell'Ariccia, G., \& Mauro, P. (2010). Rethinking macroeconomic policy. Journal of Money, Credit and Banking, 42, 199-215.

Calvo, G. A., Reinhart, C. M. (2002). Fear of floating. The Quarterly Journal of Economics, 117(2), 379- 408.

Carney, M. (2019) "The Growing Challenges for Monetary Policy in the current International Monetary and Financial System," Jackson Hole meeting.

Cerutti, E., Claessens, S., \& Laeven, L. (2017). The use and effectiveness of macroprudential policies: New evidence. Journal of Financial Stability, 28, 203-224. 
Cheah, E. T., \& Fry, J. (2015). Speculative bubbles in Bitcoin markets? An empirical investigation into the fundamental value of Bitcoin. Economics Letters, 130, 32-36.

Corbet, S., Meegan, A., Larkin, C., Lucey, B., \& Yarovaya, L. (2018). Exploring the dynamic relationships between cryptocurrencies and other financial assets. Economics Letters, 165, 28-34.

Cukierman, A. (2019). Welfare and Political Economy Aspects of a Central Bank Digital Currency.

Cukierman, A., Edwards, S., \& Tabellini, G. (1992). Seigniorage and Political Instability. American Economic Review, 82(3), 537-555.

Edwards, S. (2018). American Default: The Untold Story of FDR, the Supreme Court, and the Battle over Gold. Princeton University Press.

Eichengreen, B (2018), From Commodity to Fiat and Now to Crypto: What Does History Tell Us?" NBER working paper 25426.

"Libra: The known unknowns and unknown unknowns," VoxEu

Eichengreen, B. (2019). Globalizing capital: a history of the international monetary system. Princeton University Press.

Feng, W., Wang, Y., \& Zhang, Z. (2018). Informed trading in the Bitcoin market. Finance Research Letters, 26, 63-70.

Frankel, J. A., Vegh, C. A., \& Vuletin, G. (2013). On graduation from fiscal procyclicality. Journal of Development Economics, 100(1), 32-47.

Frankel, J. (2013). A solution to fiscal procyclicality: the structural budget institutions pioneered by Chile. Central Banking, Analysis, and Economic Policies Book Series, 17, 323-391.

Gandal, N, J T Hamrick, T Moore, and T Oberman (2018), "Price manipulation in the Bitcoin ecosystem", Journal of Monetary Economics 95: 86-96.

Gopinath G., E. Boz, C. Casas, F. J. Díez, P.O. Gourinchas, and M. Plagborg-Møller. (2019). Dominant Currency Paradigm. NBER Working Paper No. 22943.

Gourinchas P.O., H. Rey, and M. Sauzet (2019). The International Monetary and Financial System. NBER Working Paper No. 25782.

Ghosh, A. R., Ostry, J. D., Chamon, M. (2016). Two targets, two instruments: Monetary and exchange rate policies in emerging market economies. Journal of International Money and Finance, 60, 172- 196.

Kalemli-Özcan K. (2019). U.S. Monetary Policy and International Risk Spillovers NBER Working Paper No. 26297 September 2019.

Korinek, A. (2011). The new economics of prudential capital controls: A research agenda. IMF Economic Review, 59(3), 523-561.

Klein, M. W. (2012). Capital controls: gates versus walls. Brookings Papers on Economic Activity, vol 2012(1), pages 317-367.

Klein, M. W., \& Shambaugh, J. C. (2015). Rounding the corners of the policy trilemma: sources of monetary policy autonomy. American Economic Journal: Macroeconomics, 7(4), 33-66.

Lagarde, C (2018), "Winds of Change: The Case for New Digital Currency," speech at Singapore Fintech Festival, November 14.

Mundell, R. (1969). Toward a better international monetary system. Journal of Money, Credit and Banking, 1(3), 625-648. 
Nakamoto, S. (2008). Bitcoin: A peer-to-peer electronic cash system.

Niepelt, D. (2019). Libra paves the way for central bank digital currency, VoxEu

Obstfeld, M., Ostry, J. D., \& Qureshi, M. S. (2019). A tie that binds: Revisiting the trilemma in emerging market economies. Review of Economics and Statistics, 101(2), 279-293.

Ostry, J. D. (2012). Managing Capital Flows: What Tools to Use?. Asian Development Review, 29(1), 82.

Jordà, Ò., Schularick, M., \& Taylor, A. M. (2015). Leveraged bubbles. Journal of Monetary Economics, 76, S1-S20.

Rajan, R. G. (2005). Has Financial Development Made the World Riskier? (No. w11728). National Bureau of Economic Research.

Rajan, R. G., \& Zingales, L. (2004). Saving capitalism from the capitalists: Unleashing the power of financial markets to create wealth and spread opportunity. Princeton University Press.

Rey, H. (2013). pDilemma not Trilemma: The Global Financial Cycle and Monetary Policy Independence, qin Global Dimensions of Unconventional Monetary Policy. In Proceedings of the 2013 Federal Reserve Bank of Kansas City Economic Policy Symposium (Vol. 285, p. 333).

Rodrik, D. (2006). The social cost of foreign exchange reserves. International Economic Journal, 20(3), 253-266.

(2019). Putting Global Governance in its Place. NBER WP 26213 w26213

Rose, A (2007), "A stable international monetary system emerges: Inflation targeting is Bretton Woods, reversed", Journal of International Money and Finance 26(5): 663-681.

Roubini, N (2018), "Crypto is the Mother of All Scams and (Now Busted) Bubbles While Blockchain Is The Most Over-Hyped Technology Ever, No Better than a Spreadsheet/Database", Testimony for the Hearing of the US Senate Committee on Banking, Housing and Community Affairs, October.

Sanches, D. (2016). On the inherent instability of private money. Review of Economic Dynamics, 20, 198-214.

Sargent, T. J., Wallace, N. (1981). Some unpleasant monetarist arithmetic. Federal Reserve Bank of Minneapolis Quarterly Review, 5(3), 1-17.

Shin, H. S. (2011). Macroprudential policies beyond Basel III. BIS papers, 1(5).

Taylor, J. B. (1993, December). Discretion versus policy rules in practice. In Carnegie-Rochester conference series on public policy (Vol. 39, pp. 195-214). North-Holland.

Tinbergen, J. (1952). On the theory of economic policy. Books (Jan Tinbergen).

Vandenbussche, J., Vogel, U., \& Detragiache, E. (2015). Macroprudential policies and housing prices: A new database and empirical evidence for Central, Eastern, and Southeastern Europe. Journal of Money, Credit and Banking, 47(S1), 343-377.

Zhang, L., \& Zoli, E. (2016). Leaning against the wind: Macroprudential policy in Asia. Journal of Asian Economics, 42, 33-52. 


\section{USD Share of Global Official Reserves $\%$ of allocated reserves}

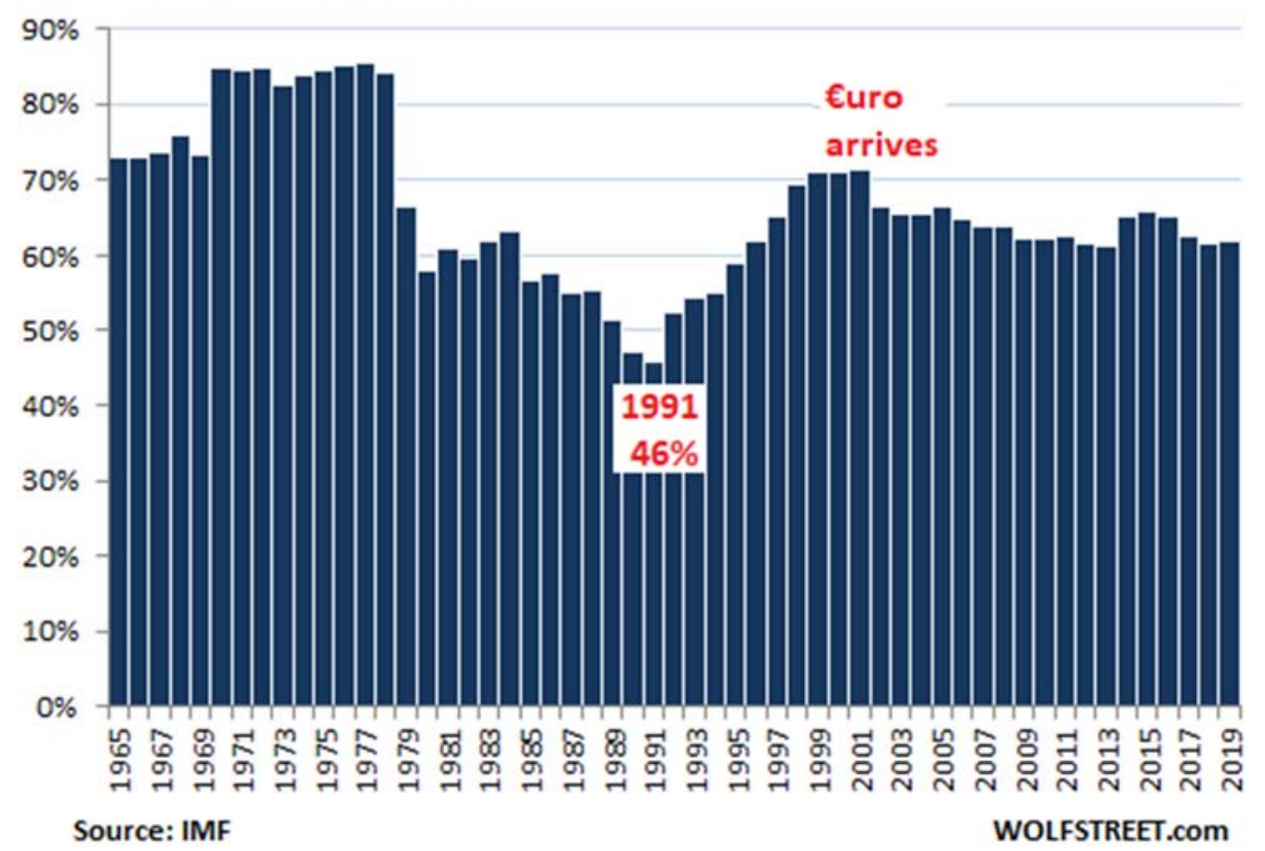

Figure 1

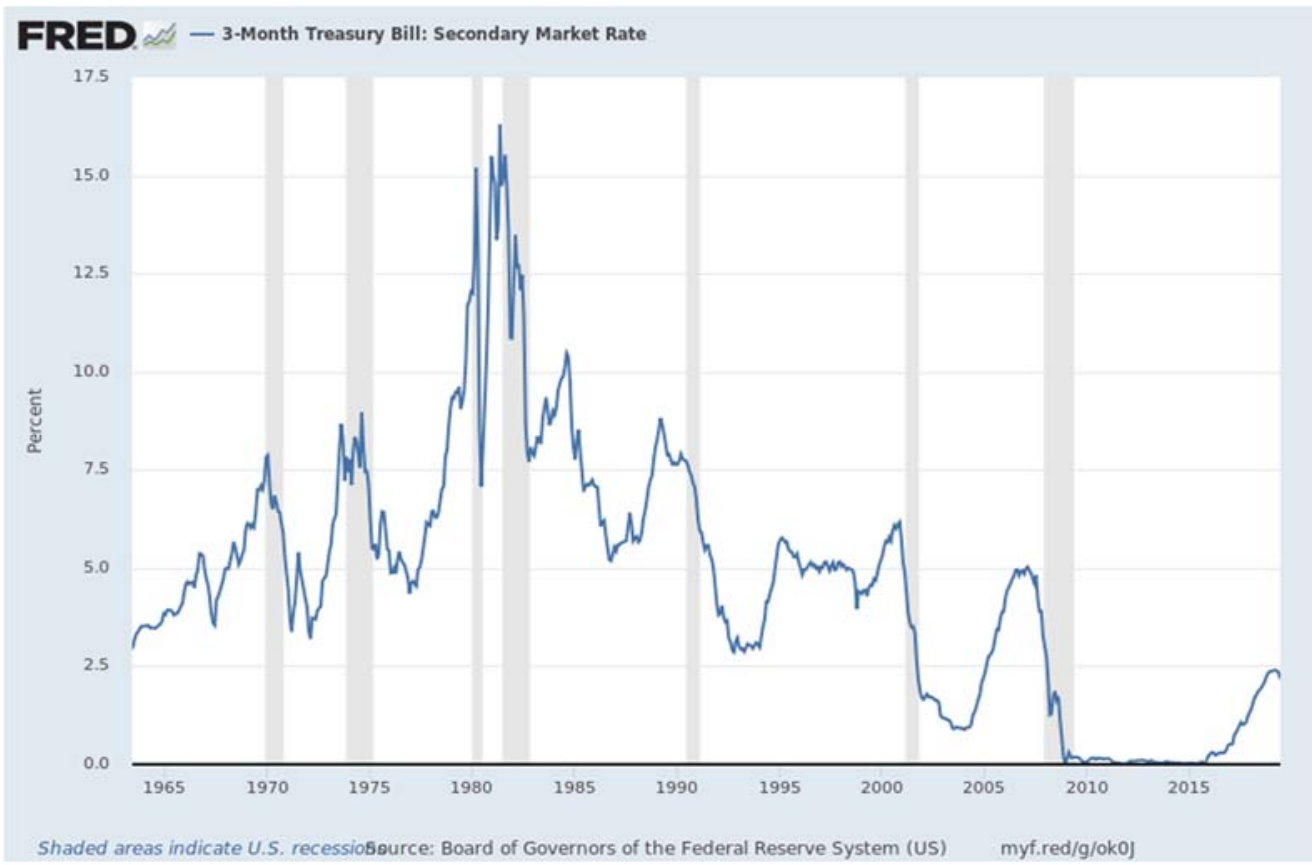

Figure 2a: 3-month US T Bills 


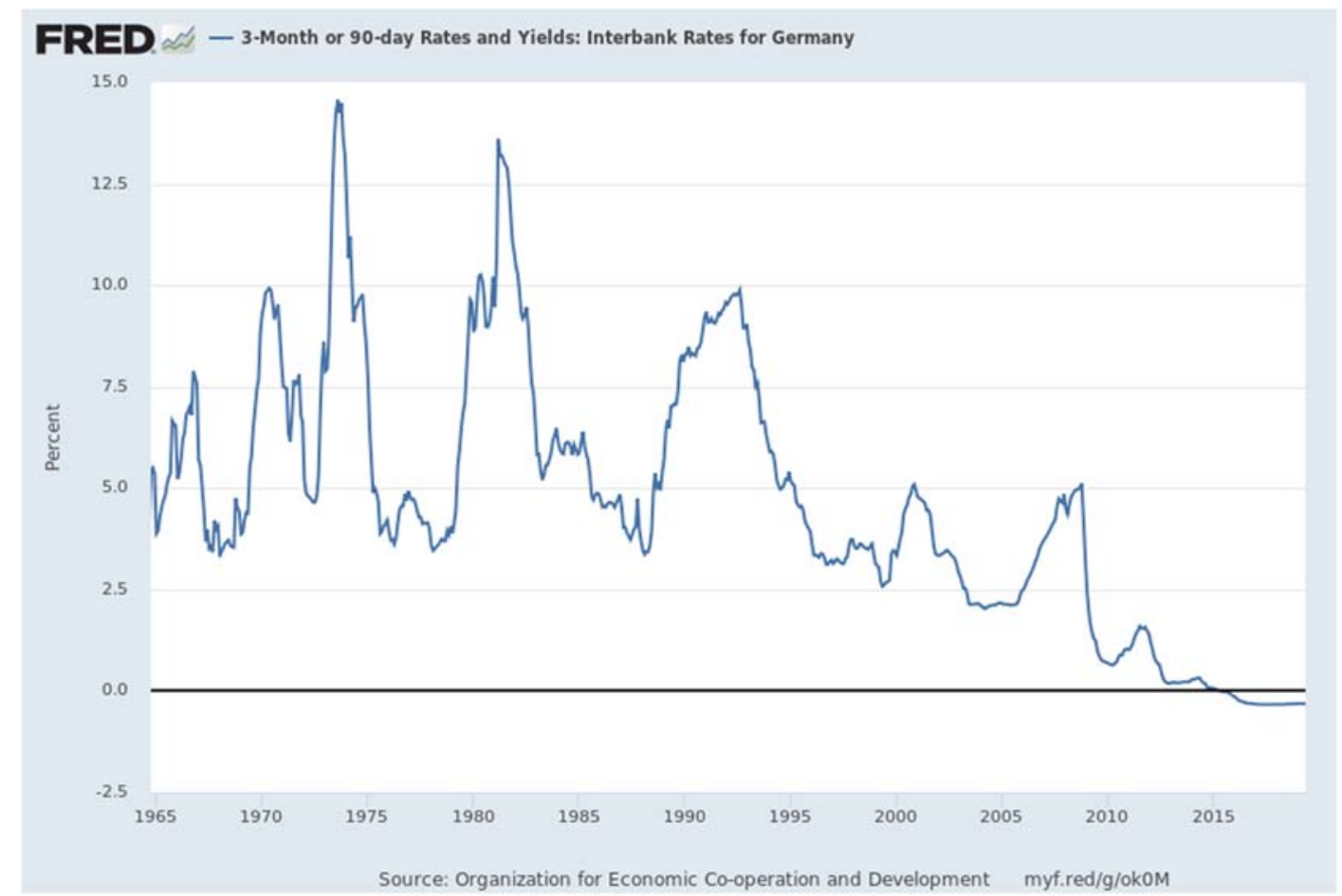

Figure 2b: 90-day rates for Germany

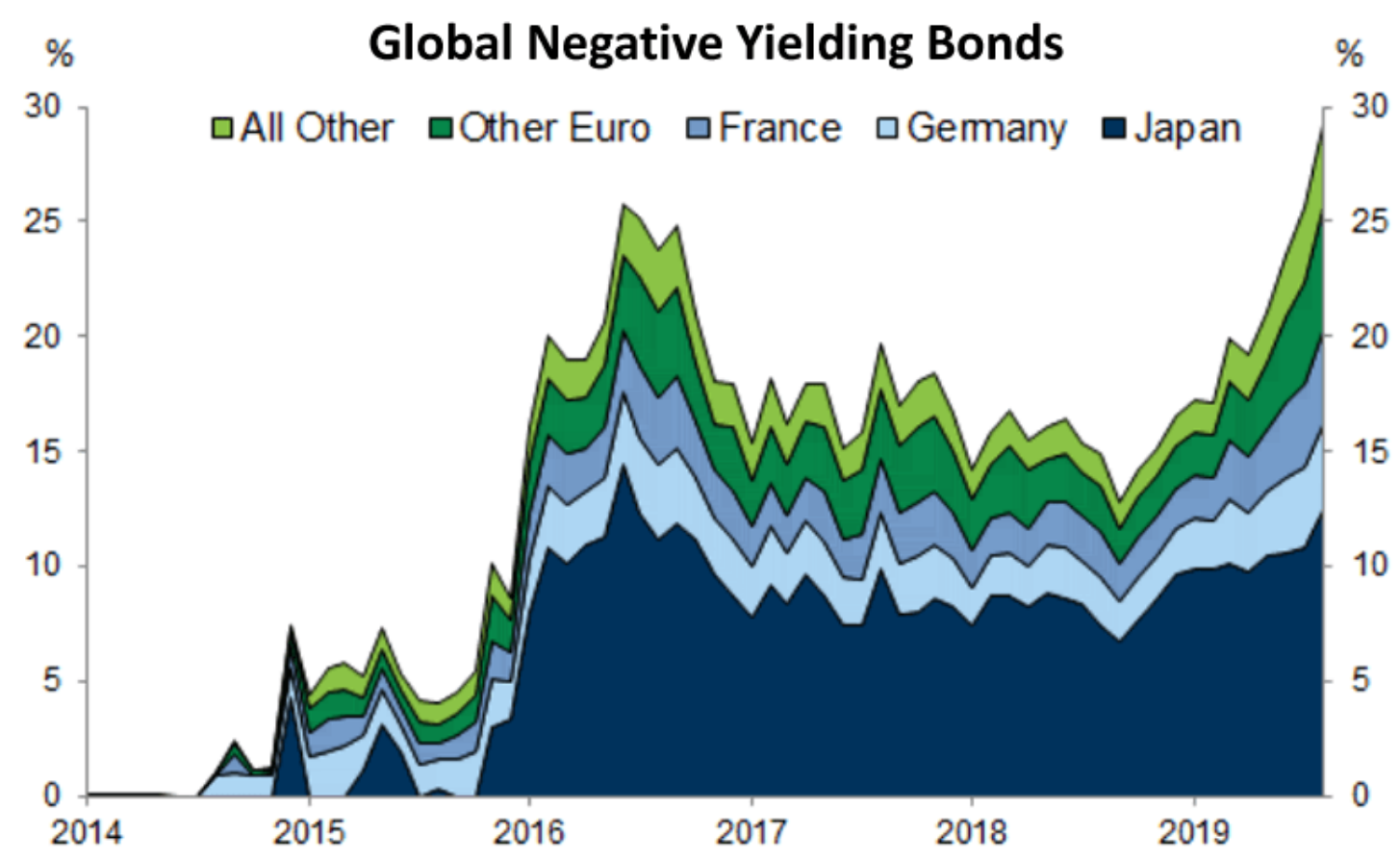

Source: Bloomberg, Goldman Sachs Global Investment Research

Figure 2c Global share of negative yielding debt 


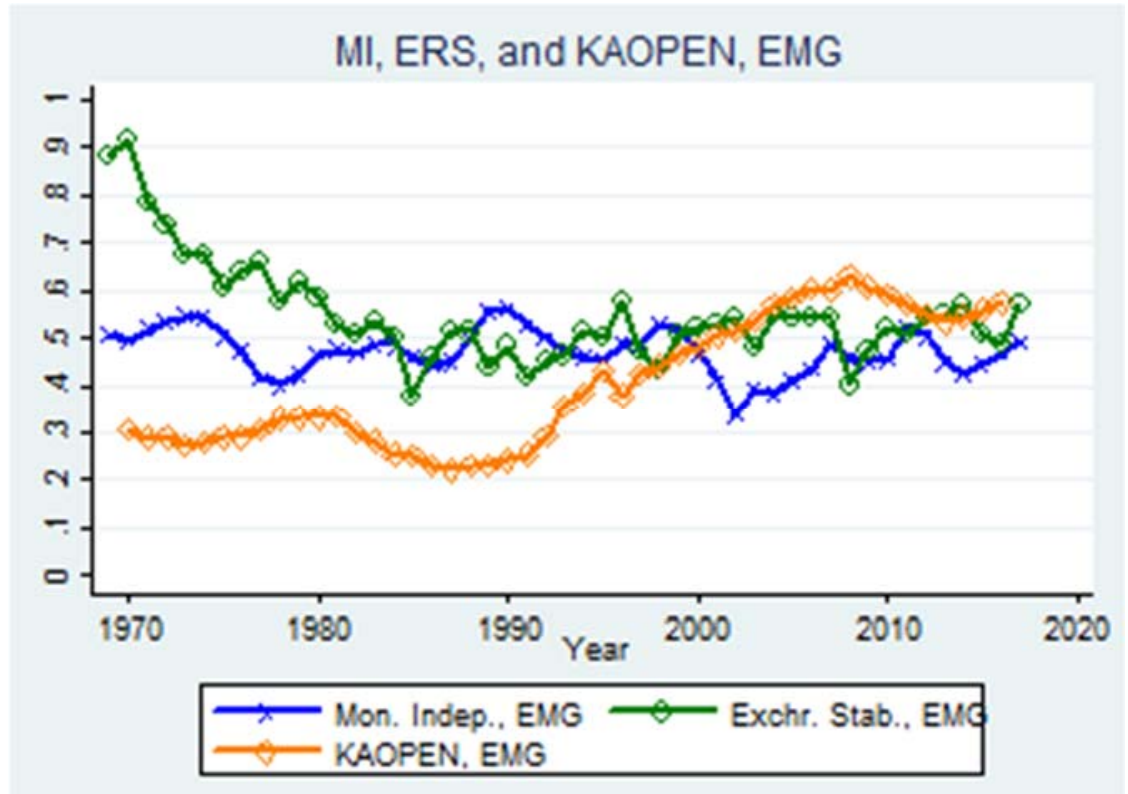

Figure 3: EMs convergence to the Trilemma Middle Ground

Sources: http://web.pdx.edu/ ito/trilemma_indexes.htm; Overviewed in Aizenman (2019) 
Investors increased allocations to emerging market bond and equity funds in early 2019.

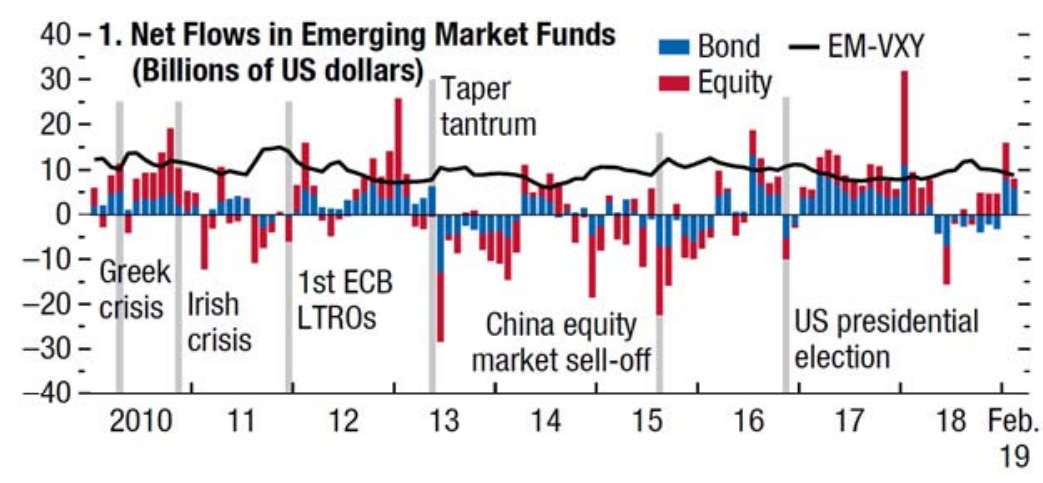

Note: Capital inflows are net purchases of domestic assets by nonresidents.

Capital outflows are net purchases of foreign assets by domestic residents.

Emerging Asia excluding

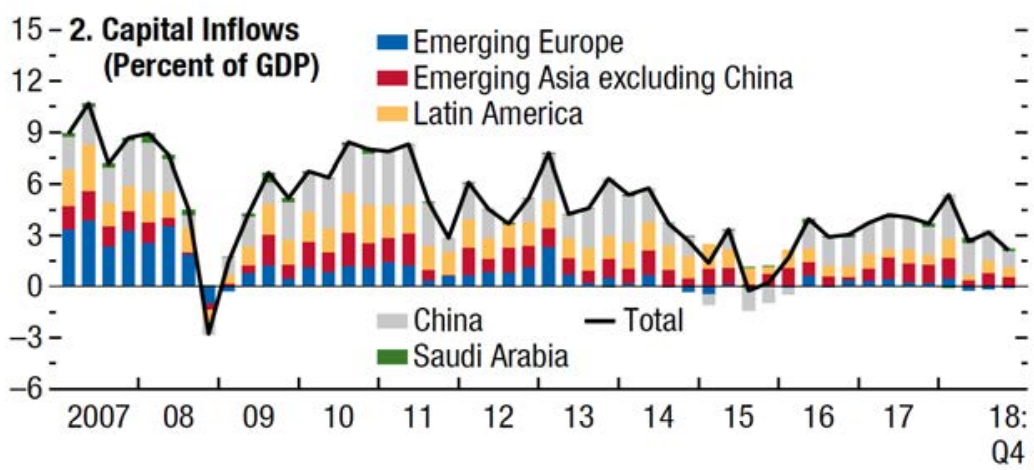

15 - 3. Capital Outflows Excluding Change in Reserves

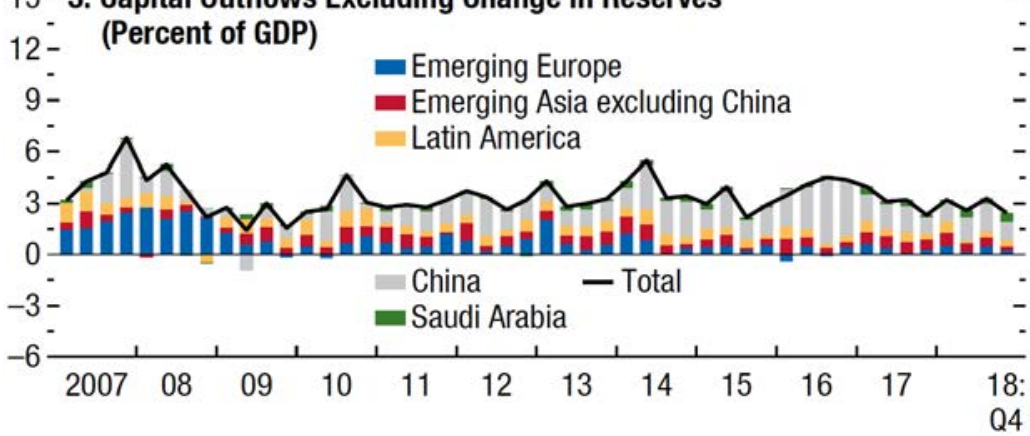

\section{5 - 4. Change in Reserves}

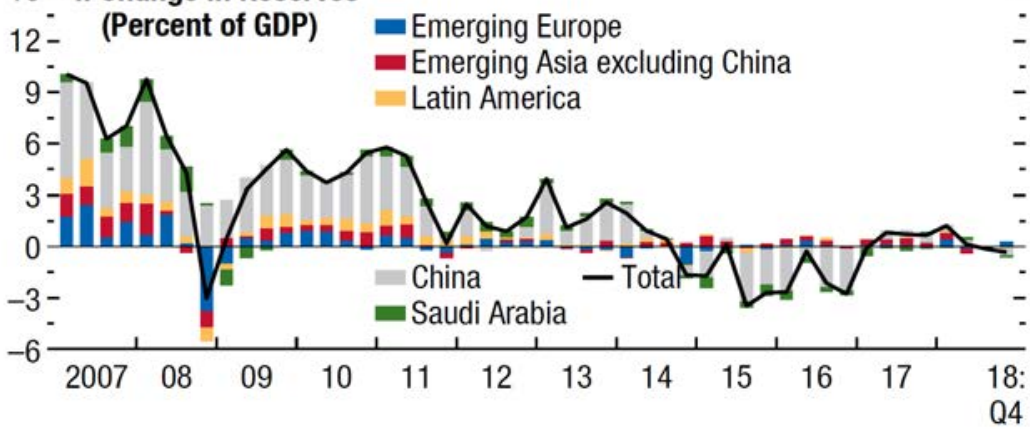

China comprises India, Indonesia, Malaysia, the Philippines, and Thailand; emerging Europe comprises Poland, Romania, Russia, and Turkey; Latin America comprises Brazil, Chile, Colombia, Mexico, and Peru.

$\mathrm{ECB}=$ European Central Bank;

$E M-V X Y=J . P$. Morgan

Emerging Market

Volatility Index;

LTROs = long-term refinancing operations.

Figure 4 Emerging Market Economies: Capital Flows. Source: WEO April 2019 


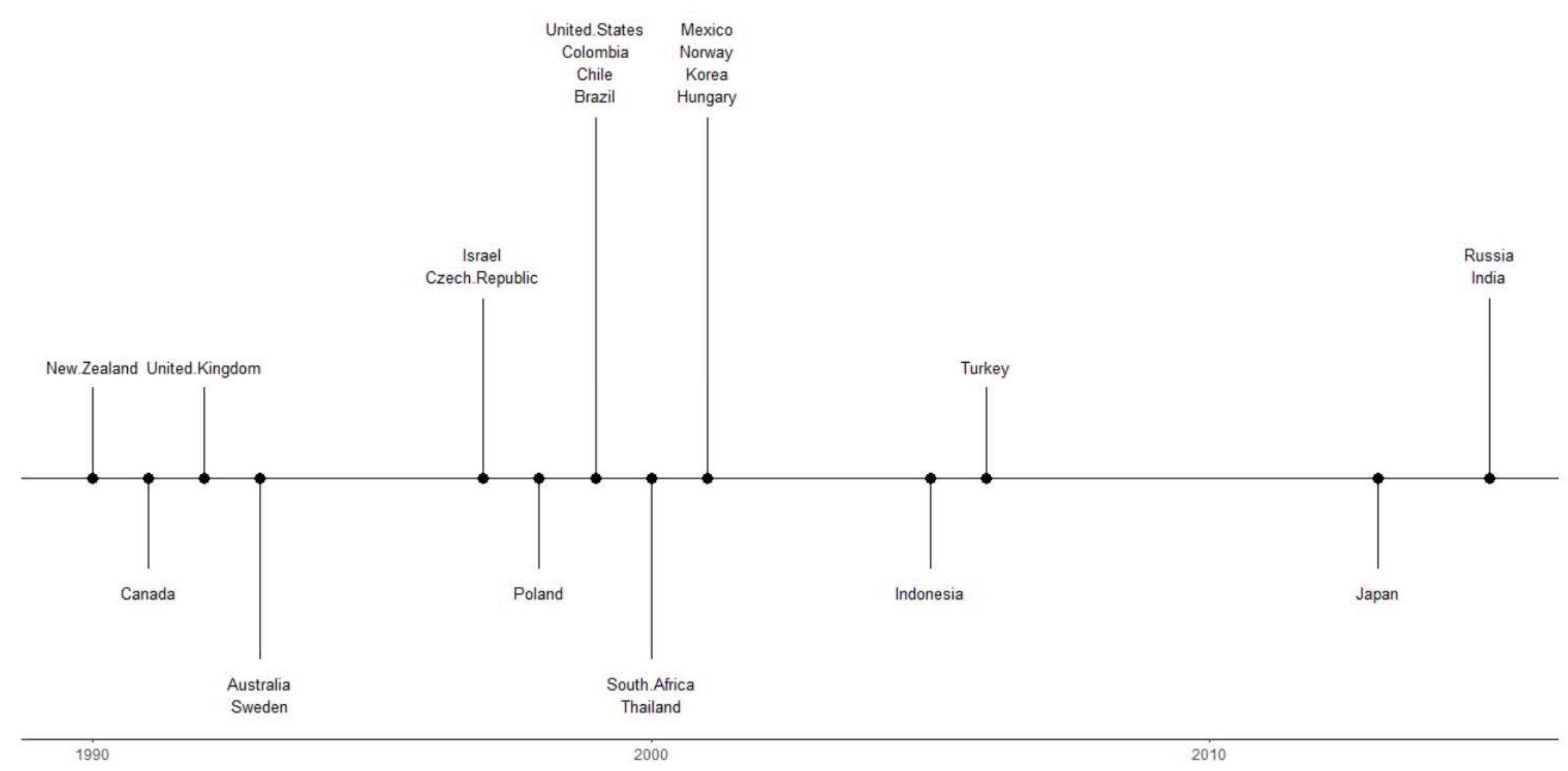

Figure 5: IT diffusion Sources: Ahmed, Aizenman, Jinjarak (2019) 


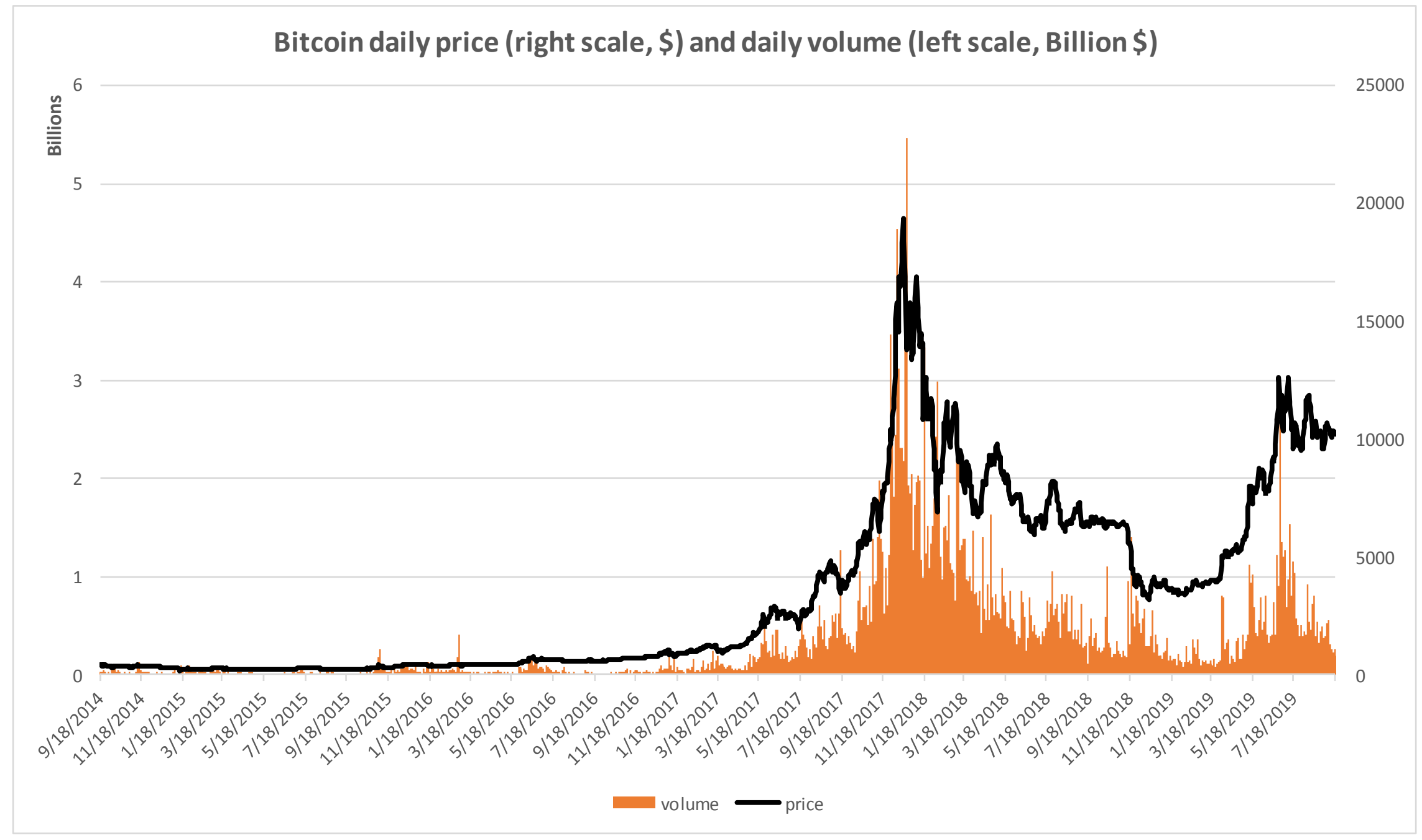

Figure 6: Bitcoin daily prices (right axis, \$/BTC) and volume (left axis, Billion $\$$ ); https://data.bitcoinity.org/markets/price volume/5y/USD?r=day\&t= 